\title{
Insights from monkey malaria that can change thinking about human infections
}

\author{
Janet Cox-Singh \\ From Parasite to Prevention: Advances in the understanding of malaria \\ Edinburgh, UK. 20-22 October 2010
}

Despite prolonged and intense effort to understand and control the health impact of malaria morbidity and mortality, malaria remains third in the global ranking for severe and fatal infections. P. falciparum is responsible for most malaria morbidity and mortality [1]. The more widespread Plasmodium vivax is considered less pathogenic but now appears to cause severe acute disease with some fatal cases [2]. Nevertheless among the human malarias virulent acute $P$. falciparum malaria attracts most research attention.

Falciparum malaria has several characteristics notfound in $P$. vivax or the other two human adapted species, Plasmodium ovale and Plasmodium malariae. Differences include parasitemias $>100000 / \mathrm{uL}$ and the ability to sequester from the peripheral blood in deep post-capillary venules. Both are strong contenders for increased pathophysiology in this species. Unfortunately because of few similarities between the four human-host malarias it is difficult distinguish virulence factors from interspecies differentiation.

The monkey malaria, Plasmodium knowlesi may change this and our views on malaria pathophysiology. The discovery of severe and fatal cases of knowlesi malaria in the human population was unexpected and for the first time offers a comparator disease for falciparum malaria. In Sarawak, Malaysian Borneo $10 \%$ of $P$. knowlesi cases are complicated, with at least $1 \%$ of all human cases becoming fatal [3]. Complicated knowlesi malaria presents as organ dysfunction, acute and delayed acute respiratory distress syndrome, but not coma or severe malarial anaemia that are often associated with falciparum malaria. Preliminary studies show a direct correlation between $P$. knowlesi parasitemia and complications, parasitemias $>100000 / \mathrm{uL}$ are common. Blood vessels in the brain from a fatal knowlesi case were congested with sequestered heavily pigmented mature stage parasites [4]. The patient did not present with cerebral malaria, a complication often associated with $P$. falciparum sequestration in post capillaries of the brain.

Descriptions of naturally acquired $P$. knowlesi malaria in humans are enhanced by the wealth of baseline molecular information available for $P$. knowlesi gathered from experimental primate infections and the knowlesi genome project [5]. P. knowlesi is permissive in various primates and some infections are representative of human knowlesi malaria. Pathophysiology of naturally acquired P. knowlesi malaria in humans and P. falciparum compare well and there are important differences. Comparisons will lead to the identification of testable candidate virulence factors. The ability to specifically test virulence in representative primate models may well offer much needed means to understand malaria pathophysiology and to help distinguish $P$. falciparum virulence from inconsequential species-specific characteristics.

Published: 20 October 2010

\section{References}

1. WHO: MalaFact Sheet No. 94. World Health Organization, January 2009 2009.

2. Tjitra E, Anstey NM, Sugiarto P, Warikar N, Kenangalem E, Karyana M, Lampah DA, Price RN: Multidrug-resistant Plasmodium vivax associated with severe and fatal malaria: a prospective study in Papua, Indonesia. PLoS Med 2008, 5:e128.

3. Daneshvar C, Davis TM, Cox-Singh J, Rafa'ee MZ, Zakaria SK, Divis PC, Singh B: Clinical and laboratory features of human Plasmodium knowlesi infection. Clin Infect Dis 2009, 49:852-60.

4. Cox-Singh J, Hiu J, Lucas SB, Divis PC, Zulkarnaen M, Chandran P, Wong KT, Adem P, Zaki SR, Singh B, Krishna S: Severe malaria-a case of fatal Plasmodium knowlesi infection with post-mortem findings: a case report. Malar J 2010, 9:10. 
5. Pain $A$, Böhme $U$, Berry $A E$, Mungall $K$, Finn RD, Jackson AP, Mourier $T$, Mistry J, Pasini EM, Aslett MA, Balasubrammaniam S, Borgwardt K, Brooks K, Carret C, Carver TJ, Cherevach I, Chillingworth T, Clark TG, Galinski MR, Hall N, Harper D, Harris D, Hauser H, Ivens A, Janssen CS, Keane T, Larke N, Lapp S, Marti M, Moule S, Meyer IM, Ormond D, Peters N, Sanders M, Sanders S, Sargeant TJ, Simmonds M, Smith F, Squares R, Thurston S, Tivey AR, Walker D, White B, Zuiderwijk E, Churcher C, Quail MA, Cowman AF, Turner CM, Rajandream MA, Kocken CH, Thomas AW, Newbold Cl, Barrell BG, Berriman M: The genome of the simian and human malaria parasite Plasmodium knowlesi. Nature 2008, 455:799-803.

doi:10.1186/1475-2875-9-S2-12

Cite this article as: Cox-Singh: Insights from monkey malaria that can change thinking about human infections. Malaria Journal 2010

9(Suppl 2):12.

Submit your next manuscript to BioMed Central and take full advantage of:

- Convenient online submission

- Thorough peer review

- No space constraints or color figure charges

- Immediate publication on acceptance

- Inclusion in PubMed, CAS, Scopus and Google Scholar

- Research which is freely available for redistribution

Submit your manuscript at www.biomedcentral.com/submit 